\title{
New emerging entomopathogenic fungi isolated from soil in South Sumatra (Indonesia) and their filtrate and conidial insecticidal activity against Spodoptera litura
}

\author{
SITI HERLINDA ${ }^{1,2, \boldsymbol{v}}$, RISKI ANWAR EFENDI ${ }^{1}$, RADIX SUHARJO ${ }^{3}$, HASBI $^{2,4}$, ARUM SETIAWAN $^{5}$, ELFITA $^{6}$, \\ MARIESKA VERAWATY ${ }^{5}$ \\ ${ }^{1}$ Department of Plant Pests and Diseases, Faculty of Agriculture, Universitas Sriwijaya. Jl. Raya Palembang-Prabumulih Km 32, Indralaya, Ogan Ilir \\ 30662, South Sumatra, Indonesia. Tel.: +62-711-580663, Fax.: +62-711-580276, ”email: sitiherlinda@unsri.ac.id \\ ${ }^{2}$ Research Center for Sub-optimal Lands, Universitas Sriwijaya. J1. Padang Selasa No. 524, Bukit Besar, Palembang 30139, South Sumatra, Indonesia \\ ${ }^{3}$ Department of Plant Protection, Faculty of Agriculture, Universitas Lampung. J1. Prof. Sumantri Brojonegoro No. 1, Bandar Lampung 35145, Lampung, \\ Indonesia \\ ${ }^{4}$ Program of Agricultural Engineering, Faculty of Agriculture, Universitas Sriwijaya. Jl. Raya Palembang-Prabumulih Km 32, Indralaya, Ogan Ilir 30662, \\ South Sumatra, Indonesia \\ ${ }^{5}$ Department of Biology, Faculty of Mathematics and Natural Sciences, Universitas Sriwijaya. Jl. Raya Palembang-Prabumulih Km 32, Indralaya, Ogan \\ Ilir 30662, South Sumatra, Indonesia \\ ${ }^{6}$ Department of Chemistry, Faculty of Mathematics and Natural Sciences, Universitas Sriwijaya. Jl. Raya Palembang-Prabumulih Km 32, Indralaya, \\ Ogan Ilir 30662, South Sumatra, Indonesia
}

Manuscript received: 20 September 2020. Revision accepted: 9 October 2020

\begin{abstract}
Herlinda S, Efendi RA, Suharjo R, Hasbi, Setiawan A, Elfita, Verawaty M. 2020. New emerging entomopathogenic fungi isolated from soil in South Sumatra (Indonesia) and their filtrate and conidial insecticidal activity against Spodoptera litura. Biodiversitas 21: 5102-5113. This study was carried out to confirm identity of Beauveria bassiana and Metarhizium anisopliae using sequence analysis of Internal Transcribed Spacer (ITS) region as well as the two unknown isolates of EPF and to investigate their filtrate and conidial insecticidal activity against $S$. litura larvae. The EPF species were identified based on morphological characters and molecular analysis. Their culture filtrate and conidial bioassays were performed on S. litura larvae. The species found were Penicillium citrinum (BKbTp), Talaromyces diversus (MSwTp1), B. bassiana (BSwTd4), and M. anisopliae (MSwTp3) and have been deposited in the GenBank. All EPF species have high insecticidal activity against $S$. litura larvae. The highest larvae mortality caused by filtrate was found on $P$. citrinum $(98.67 \%)$ and not significantly different from those of $T$. diversus $(96 \%)$, but significantly different from $B$. bassiana $(86.67 \%)$ and $M$ anisopliae $(82.67 \%)$. The highest larvae mortality caused by the conidia was also occurred to $P$. citrinum (98.67\%) which was not significantly different from those of T. diversus $(97.33 \%)$, B. bassiana $(86.67 \%)$, and M. anisopliae (86.67\%). The $\mathrm{LT}_{50}$ caused by $T$. diversus filtrate was the shortest ( 6.19 days) and not significantly different from those caused by $P$. citrinum (6.62 days). The shortest $\mathrm{LT}_{50}$ caused by conidia was found on $P$. citrinum (5.45 days). Therefore, the conidia and filtrate of $P$. citrinum, a new emerging entomopathogenic fungus, has the highest insecticidal activity. P. citrinum has the potential to be developed into commercial mycoinsecticides.
\end{abstract}

Keywords: Beauveria bassiana, leaf-eating caterpillar, Metarhizium anisopliae, Penicillium citrinum, Talaromyces diversus

\section{INTRODUCTION}

South Sumatra, Indonesia has a stretch with varying topography from the height of the land to the high ground. This topographic variation can develop many species of plants, for example, vegetables and the food crops. Vegetables that can adapt to various land topography in South Sumatra include chili (Capsicum spp.), mustard greens (Brassica juncea), kale (Ipomoea reptans), and spinach (Amaranthus tricolor) (Siaga et al. 2019). The main constraints of vegetable cultivation, especially chili pests are fruit flies (Bactrocera dorsalis (Syamsudin et al. 2019), sap sucker (Thrips) (Johari et al. 2016), and leafeating caterpillar (Spodoptera litura) (Tompe et al. 2020).

S. litura is a polyphagous insect pest that attacks many plant species from various families (Tompe et al. 2020), like chili, mustard greens, water spinach, and spinach. The yield loss of chili caused by this pest reaches $50 \%$ every year (Vijayalakshmi et al. 2016). The first instar of S. litura larvae eats the leaves in groups and skeletonize them, while the second instar extends to the last instar spread and eat individually leaves, flowers, and pistil chili (Tompe et al. 2020). In addition, S. litura is a key pest for leafy vegetables, such as mustard greens, water spinach, and spinach because the leaves that have been eaten become no longer valuable (Vijayalakshmi et al. 2016; Tompe et al. 2020). Since the public awareness on good health and environmental quality is increasing, there is a need to reduce the use of synthetic pesticides and improving application of eco-friendly control strategies for $S$. litura. One of the methods is applying the entomopathogenic fungi (EPF).

Some EPF species have been shown to be effective in killing S. litura, for example, Beauveria bassiana cultured in liquid media has been shown to kill $98 \%$ of $S$. litura larvae (Ayudya et al. 2019; Gustianingtyas et al. 2020). Metarhizium anisopliae was reportedly also effective in 
killing S. litura larvae (Sowmya et al. 2017; Yang et al. 2019; Gustianingtyas et al. 2020) and can kill $96 \%$ of $S$. litura larvae (Gustianingtyas et al. 2020). Furthermore, Metarhizium rileyi also effectively kills $S$. litura larvae (Liu et al. 2017). In addition to being effective in killing the insect pests, EPF can also be integrated with entomopathogenic viruses, such as nucleopolyhedroviruses (NPV) (Souza et al. 2019) and botanical insecticides (Hernandez-Trejo et al. 2019) and does not harm parasitoids (Ngangambe and Mwatawala 2020).

Four isolates of EPF have been isolated from rhizosphere of several kinds of plants in lowland to high land of South Sumatra. On the basis of morphological characters, the two isolates have been identified as $B$. bassiana and M. anisopliae (Safitri et al. 2018; Sumikarsih et al. 2019; Gustianingtyas et al. 2020), and their filtrates were proven to be effectively killed up to $98 \%$ of $S$. litura larvae (Ayudya et al. 2019; Gustianingtyas et al. 2020). The other two EPF, until now, have not been fully revealed on molecular identity and their filtrate and conidial capability to cause mortality on S. litura. This research aimed to confirm identity of Beauveria bassiana and Metarhizium anisopliae using sequence analysis of Internal Transcribed Spacer (ITS) region as well as the two unknown isolates of EPF and to investigate their filtrate and conidial insecticidal activity against $S$. litura larvae.

\section{MATERIALS AND METHODS}

\section{Exploring EPF}

The EPF exploration was carried out on soil near root of oil palm, rice, maize, and vegetables in various locations (Table 1) ranging from lowland to highland of South Sumatra using the method of Safitri et al. (2018). Those locations chosen have objective to obtain the fungi that had adapted in the soils. The morphological identifications were carried out in 2018 and 2019, and their identities were confirmed by molecular analysis in February 2020. The EPF exploration method modified those of Anwar et al. (2015), namely using a bait method with Tenebrio molitor larvae as insect bait which was fed in the soil sample. The soil sampling used the method of Anwar et al. (2015) by digging the soil using surface soil sampler $(\varnothing 20 \mathrm{~mm})$ as deep as $10 \mathrm{~cm}$ around the rhizosphere plant according to the method of Thaochan and Sausa-Ard (2017) and 5 points were taken to collect $1 \mathrm{~kg}$ of soil. Then, the soil sample was put into a plastic bag and labeled with information about the height of the location, type of commodity, and date of collection.

The soil sample was first cleaned from the roots and sieved with a 10 mesh sieve. Then, it was put into a plastic tray $\left(32 \times 25 \times 5 \mathrm{~cm}^{3}\right)$ each containing as much as $1 \mathrm{~kg}$. The soil was then moistened with sterile distilled water with soil moisture exceeding $20 \%$ according to the method of Chen et al. (2014). Then, 20 newly molted 3rd-instar larvae of $T$. molitor were placed at the bottom of the tray and the larvae were sprinkled with the soil to reach $3 \mathrm{~cm}$ in thickness. Then, the tray containing the soil was covered with black cloth and sprayed with distilled water to maintain the soil moisture. The larvae were infested in the soil for 7 days to give time for the entomopathogenic fungal conidia to infect them, after which the dead larvae infected with entomopathogenic fungi were grown in the Sabouraud Dextrose Agar (SDA, Merck) medium.

\section{Isolation and identification of EPF}

The EPF infecting the larvae of T. molitor which was characterized by its body was overgrown with EPF mycelia, dry and contracted, then isolated and purified using the method of Youssef (2014). The isolation of EPF from the larvae's body surface began with the surface sterilization by modifying the method of Sharma et al. (2018) by rinsing with $1 \%$ of $\mathrm{NaOCl}$ for 1 minute, then rinsing with $100 \mathrm{~mL}$ of sterile distilled water for 3 times. The larvae sterilization was carried out to obtain EPF inside the haemocoel and cuticle larvae and prevent water fungi from being obtained. The sterilized larvae were grown in SDA media and incubated for 2 days. The growing fungus was purified in the SDA media until after getting pure isolates. The pure EPF was identified based on the molecular analysis.

\section{Fungal identification}

Morphological observations were carried out based on microscopic and macroscopic characteristics of the EPF. The macroscopic observation of the fungi was based on the color and shape of colony, whereas the microscopic observation was based on the shape and size of conidia and conidiophores.

The EPF was identified based on the molecular analysis in February 2020 at the Laboratory of Agricultural Biotechnology (accredited according to the ISO/IEC 17025 standard), Department of Plant Protection, Faculty of Agriculture, Universitas Lampung, Indonesia.

Table 1. Locations of EPF in South Sumatra, Indonesia

\begin{tabular}{|c|c|c|c|c|c|c|}
\hline Fungal species (codes) & Village, District/City & Ecosystem & Crop & $\begin{array}{c}\text { GPS } \\
\text { (coordinate) }\end{array}$ & $\begin{array}{l}\text { Altitude } \\
\text { (m) }\end{array}$ & $\begin{array}{l}\text { GenBank } \\
\text { Acc. No. }\end{array}$ \\
\hline $\begin{array}{l}\text { Penicillium citrinum } \\
\text { (BKbTp) }\end{array}$ & $\begin{array}{l}\text { Talang Patai, Pagar } \\
\text { Alam }\end{array}$ & Highland soil & Cabbage & $\begin{array}{l}\text { S } 04^{\circ} 02.161^{\prime} \\
\text { E } 103^{\circ} 10.484^{\prime}\end{array}$ & 175 & MT448730 \\
\hline $\begin{array}{l}\text { Talaromyces diversus } \\
\text { (MSwTp1) }\end{array}$ & $\begin{array}{l}\text { Talang Patai, Pagar } \\
\text { Alam }\end{array}$ & Highland soil & Mustard & $\begin{array}{l}\mathrm{S} 03^{\circ} 50.174^{\prime}, \mathrm{E} \\
103^{\circ} 31.2933^{\prime}\end{array}$ & 193 & MT448731 \\
\hline $\begin{array}{l}\text { Beauveria bassiana } \\
\text { (BSwTd4) }\end{array}$ & $\begin{array}{l}\text { Talang Dabok, Ogan } \\
\text { Komering Ilir }\end{array}$ & Peat soil & Oil palm & $\begin{array}{l}\text { S 0323.570' } \\
\text { E } 104^{\circ} 51.498^{\prime}\end{array}$ & 24 & MT448732 \\
\hline $\begin{array}{l}\text { Metarhizium anisopliae } \\
\text { (MSwTp3) }\end{array}$ & $\begin{array}{l}\text { Talang Patai, Pagar } \\
\text { Alam }\end{array}$ & Highland soil & Mustard & $\begin{array}{l}\mathrm{S} 03^{\circ} 50.174^{\prime}, \mathrm{E} \\
103^{\circ} 31.2933^{\prime}\end{array}$ & 193 & MT448733 \\
\hline
\end{tabular}


Table 2. Primer used for amplification

\begin{tabular}{lcccc}
\hline Target of amplification & Primer name & Sequence (5'-3') & Product size (bp) & Reference \\
\hline Internal Transcribe & ITS1 & TCC GTA GGT GAA CCT TGC GG & 600 & (White et al. 1990) \\
Spacer Region & ITS4 & TCC TCC GCT TAT TGA TAT GC & & \\
\hline
\end{tabular}

\section{DNA extraction and PCR amplification}

The DNA extraction was performed on the mycelium of 7 days old fungi using InstaGene ${ }^{\mathrm{TM}}$ Matrix (BioRad). Amplification was carried out by Sensoquest Thermal Cycler Machine (Germany). PCR amplification on Internal Transcribed Spacer (ITS) region was conducted using primer ITS1 and ITS4 (Table 2) (White et al. 1990). The PCR was carried out with total volume of $25 \mu \mathrm{L}$ involving $12.5 \mu \mathrm{L}$ Master Mix (Red Mix) (Bioline), $1 \mu \mathrm{L}$ of $10 \mu \mathrm{M}$ of primer ITS 1 and ITS $4,2 \mu \mathrm{L}$ DNA, and $8.5 \mu \mathrm{L}$ of sterile distilled water. DNA amplification consists of 1 cycle of the initiation at $95^{\circ} \mathrm{C}$ for $5 \mathrm{~min}, 30$ cycles of denaturation at $95^{\circ} \mathrm{C}$ for 1 minute, primer annealing at $52^{\circ} \mathrm{C}$ for $1 \mathrm{~min}$, primer extension at $72^{\circ} \mathrm{C}$ for 1 minute, and one cycle of elongation at $72^{\circ} \mathrm{C}$ for 5 minutes. The PCR results were run using $0.5 \%$ agarose gel in $20 \mathrm{~mL}$ of $1 \mathrm{x}$ buffer Tris-Boric Acid-EDTA (TBE) ( $1^{\text {st }}$ Base Malaysia) with 1 $\mu \mathrm{L}$ Ethidium Bromide (EtBr $10 \quad \mathrm{mg} \quad \mathrm{mL}^{-1}$ ). The electrophoresis was performed by $1 \mathrm{x}$ TBE buffer at 50 volts for 70 minutes. The results were visualized by DigiDoc UV transilluminator (UVP, USA).

The PCR product was emitted to $1^{\text {st }}$ Base Malaysia for sequencing. The sequencing results were analyzed with Bio Edit program ver. 7.2.6 for windows. The result was then submitted to Basic Local Alignment Search Tool (BLAST) (https://blast.ncbi.nlm.nih.gov/Blast.cgi) to find their potential identity. The phylogenetic tree was developed by Mega 7 for Windows (Kumar et al. 2016) with Unweighted-pair Group Method with Arithmetic means (UPGMA). Reference strains employed in this research were obtained from NCBI (https://www.ncbi.nlm.nih.gov/).

\section{Spodoptera litura mass rearing}

S. litura larvae used in the insecticide activity test was collected from the vegetable fields around the campus of Universitas Sriwijaya and those vegetable fields that were not sprayed with synthetic insecticides. The larvae were taken to the laboratory and maintained in plastic containers (Ø $25 \mathrm{~cm}$, height $30 \mathrm{~cm}$ ) topped with gauze. that has been washed thoroughly using detergent. Next, pesticide-free spinach (Ipomoea aquatic) was put into the containers for the first instar feed of $S$. litura. The second instar was fed mulberry leaves (Morus alba) planted in the experimental field of the Faculty of Agriculture, Universitas Sriwijaya, Indonesia and not sprayed with pesticides.

Every day the larvae feed was replaced with fresh new feed. The larvae entering the pupae stage were transferred into plastic containers $(\varnothing 10 \mathrm{~cm}$, height $15 \mathrm{~cm})$ whose top was exposed and the base was sprinkled with sifted soil (10 mesh). and already sterilized in an oven for 1 hour at $100^{\circ} \mathrm{C}$. The thickness of the soil in the container was $3 \mathrm{~cm}$. This plastic container containing pupae was put into a gauze cage $\left(30 \times 30 \times 30 \mathrm{~cm}^{3}\right)$ already tapped with 10 water spinach sticks for laying eggs to the adults. The hatched eggs were transferred into a plastic cylinder and fed with water spinach which was replaced every day. The larvae used for toxicity testing were the second instar of the third offspring (F3) or afterward.

\section{Producing of EPF mycoinsecticides}

The EPF already identified molecularly, namely $P$. citrinum, $T$. diversus, B. bassiana, and M. anisopliae were made liquid formulation mycoinsecticides. The mycoinsecticides made of four types, each of which had active ingredients $P$. citrinum, $T$. diversus, B. bassiana, and M. anisopliae, and sterile distilled water was used for control. The mycoinsecticides were made by the method of Mascarin et al. (2015). In this, EPF was cultivated in solid media of Sabouraud Dextrose Agar (SDA, Merck), incubated for 7 days, and then the fungal cultures that grew were transferred to the liquid media of Sabouraud Dextrose Broth (SDB, Merck). The broth fungal cultures were incubated using a shaker for 7 days at $120 \mathrm{rpm}$. The broth fungal cultures from SDB with a minimum density of $1 \times 10^{9}$ conidia $\mathrm{mL}^{-1}$ were used for the active ingredient mycoinsecticides. The mycoinsecticides were made liquid formulation containing a mixture of $600 \mathrm{~mL}$ of the broth fungal cultures, $400 \mathrm{~mL}$ of carrier from shrimp shell flour compost extract, $10 \mathrm{~mL}$ of vegetable oil, and $10 \mathrm{~mL}$ of sterile distilled water solution of $0.04 \%$ polyoxyethyl- 189 ene sorbitan mono-oleate (Tween ${ }^{\circledR}$ ). The shrimp skin flour compost extract was made using the method of Suwandi et al. (2012). After that, the formulation was stored for 30 days before it was applied to obtain stable and noncontaminant mycoinsecticides. The mycoinsecticides activity was tested in the form of EPF culture and conidia filtrate.

\section{Culture filtrate preparation of the mycoinsecticides.}

The presence of raw secondary metabolites in culture filtrate was performed according to Soesanto et al. (2019) can be done by filtering fungal broth or liquid mycoinsecticides. The culture filtrate of liquid mycoinsecticides was produced from 2 stages of filtering using the method of Ayudya et al. (2019). In the first stage, $100 \mathrm{~mL}$ liquid mycoinsecticides was filtered using Whatman filter paper no. 42 and cotton with a thickness of $1 \mathrm{~cm}$. The filtration culture produced from the first stage filter was then sucked up to $10 \mathrm{~mL}$ using a sterile hypodermic syringe to be filtered in the second stage. The second stage filtering used a syringe filter $(0.45 \mu \mathrm{m}$ pore size, Sartorius). The method of installing the syringe filter used the method of Alhusein et al. (2016) by placing it at the base of the needle, by the way, the needle was removed 
first from the syringe, then the syringe filter was installed at the base of the needle. After the syringe filter was installed at the base of the needle, the needle was re-fitted to the syringe. The syringe containing $10 \mathrm{~mL}$ was pressed so that it released the culture filtrate that escaped from the syringe filter. The $100 \mathrm{~mL}$ of mycoinsecticide produced \pm $70 \mathrm{~mL}$ of culture filtrate. According to Soesanto et al. (2019), this second filtering culture filtrate was the raw secondary metabolites. Next, the culture filtrate was measured by its insecticidal activity by taking as much as 1 $\mathrm{mL}$ to be dropped on a piece of chili leaves.

\section{Bioassays of culture filtrate and conidia of EPF}

Bioassays of culture filtrate from mycoinsecticides of P. citrinum, T. diversus, B. bassiana, and M. anisopliae were carried out on chili leaves sprayed with $1 \mathrm{~mL}$ of culture filtrate. As a control, sterile distilled water was dripped on chili leaves. Then the leaves were dried before putting 25 second-instar $S$. litura larvae which were fasted for 2 hours. The second instar larvae were let to eat the leaves for 6 hours which had been dropped by the culture filtrate. After 6 hours the larvae were transferred into a plastic cylinder topped with gauze $(\varnothing 25 \mathrm{~cm}$, height $30 \mathrm{~cm})$ containing 15-30 pieces of chili leaves (depending on the instar) which were clean and not dripped with culture filtrate. To maintain the moisture of chili leaves, the stalk was wrapped in cotton wool moistened with sterile distilled water. Every day chili leaves were replaced with new fresh leaves. The weight of the leaves eaten was measured according to the method of Ayudya et al. (2019) and recorded daily. Every day the dead larvae were recorded up to 12 days after the application.

Bioassays of conidia from mycoinsecticides of $P$. citrinum, T. diversus, B. bassiana, and M. anisopliae were carried out by means of 25 -second instar $S$. litura larvae dripped topically $1 \mathrm{~mL}$ of conidia suspension of EPF with a concentration of $1 \times 10^{6}$ conidia $\mathrm{mL}^{-1}$. Then, the larvae were fed 15-30 pieces of chili leaves. As a control, it was used sterile distilled water. The weight of leaves eaten by larvae and weight of the larvae were recorded daily. Every day the dead larvae were recorded up to 12 days after the application.

The number of dead larvae was used to calculate mortality and the median Lethal Time $\left(\mathrm{LT}_{50}\right)$. The weight of the chili leaves eaten and the bodyweight of the larvae were measured every day from the first day to 12 days after the application. The measurement of the eaten leaf weight was conducted to determine whether the EPF affected the larvae appetite, whereas the measurement of larvae body weight was carried out to determine whether or not the EPF influenced the larvae growth.

\section{Data analysis}

The data differences among the treatments for edible leaf weight, larvae weight, larvae mortality, and $\mathrm{LT}_{50}$ were analyzed using Analysis of Variance (ANOVA) if there were differences, then further tests were carried out using the 5\% Tukey's Honestly Significant Difference (HSD). $\mathrm{LT}_{50}$ data were obtained from probit analysis. All calculations were conducted using software of SAS University Edition 2.7 9.4 M5.

\section{RESULTS AND DISCUSSION}

\section{Species of EPF}

There were 4 EPF species namely, $P$. citrinum, $T$. diversus, B. bassiana, and M. anisopliae found from lowland and highland soils in South Sumatra. The macroscopic and microscopic appearance of the four fungal species showed obvious differences (Figures 1 and 2).

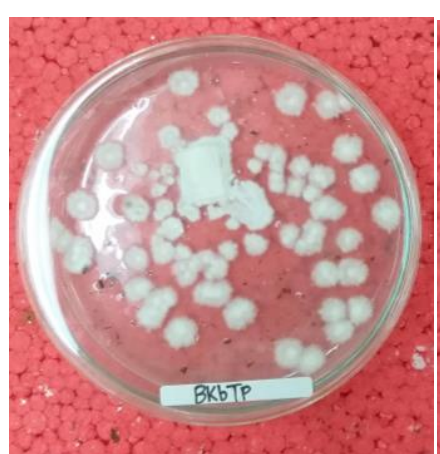

A

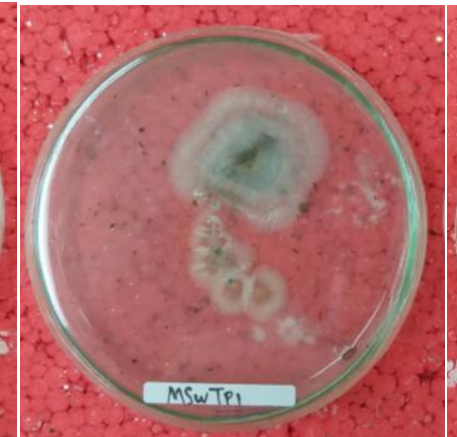

B

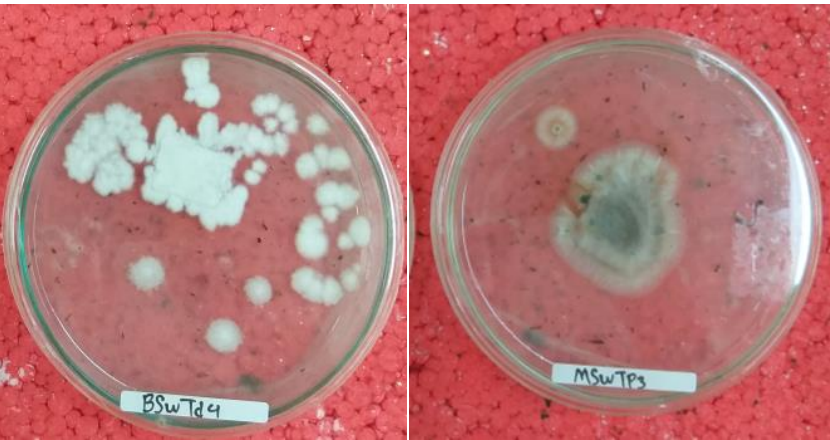

C
D

Figure 1. Colony of Penicillium citrinum (A), Talaromyces diversus (B), Beauveria bassiana (C), and Metarhizium anisopliae 


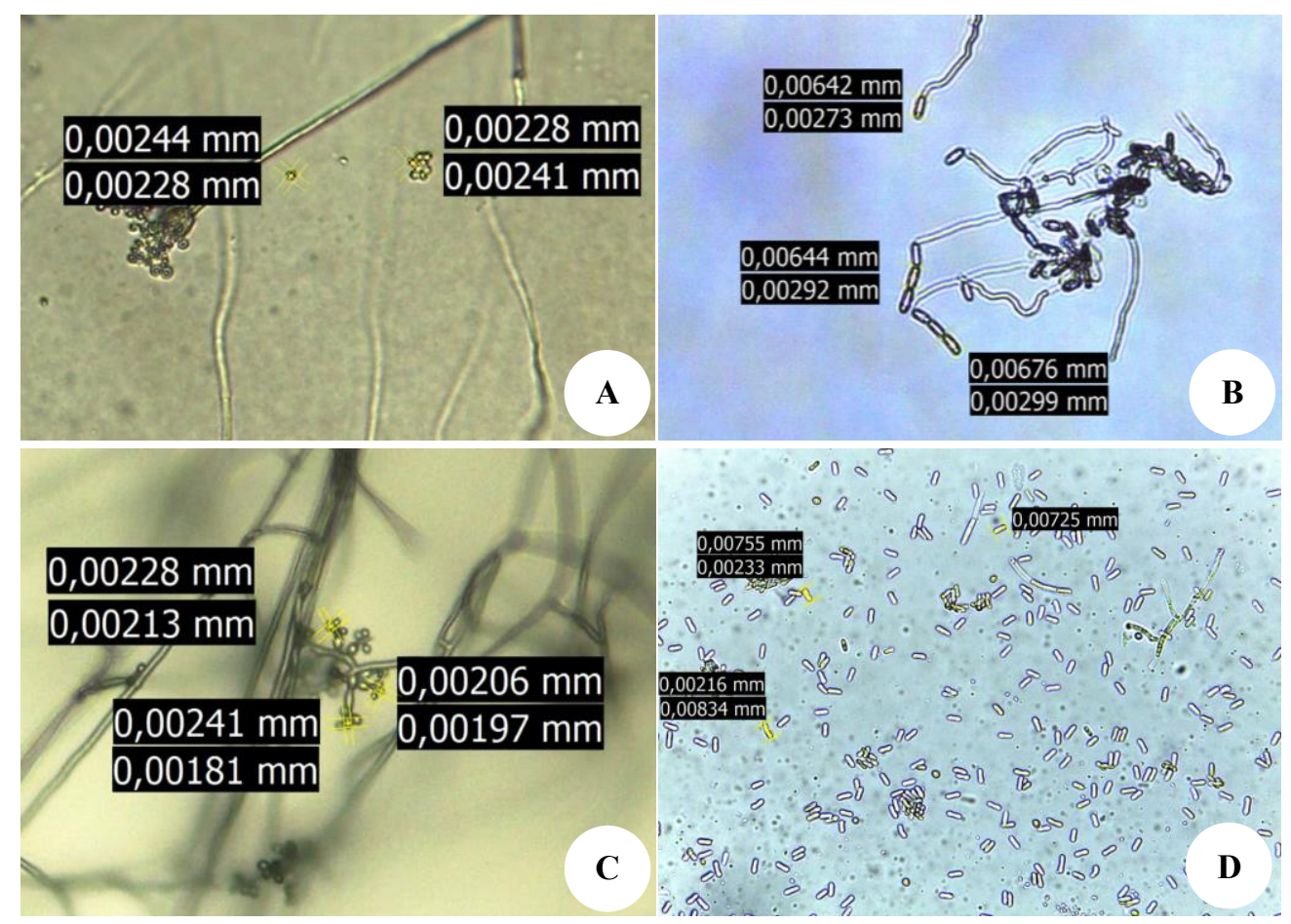

Figure 2. Conidia of Penicillium citrinum (A), Talaromyces diversus (B), Beauveria bassiana (C), and Metarhizium anisopliae (D)

The colony characteristics of $P$. citrinum on SDA medium were initially white, the older the fungus, the color turned to bluish-green with a white margin, round conidia with a diameter of 2.01-2.28 $\mu \mathrm{m}$. The characteristics matched the description described by Mathew et al. (2010) stating that $P$. citrinum has globose green granular conidia. $T$. diversus has a colony characteristic generally in the form of microcolony scattering in the medium; the color was dark green with yellow margins. According to Visagie and Jacobs (2012), the size of $T$. diversus colony ranged from 2-4 $\mathrm{mm}$ and sometimes only microcolony and produced yellow colored mycelia at colony peripheral zones. In this study, $T$. diversus was more difficult to culture than the other three species and showed poor growth of colony on SDA. B. bassiana had a colony that was white but when it got older it was yellowish or turbid white and B. bassiana colonized SDA faster than the other three species. Conidia of $B$. bassiana was one-celled and the same circular shape as the observation of Safitri et al. (2018). M. anisopliae had a colony that was also white initially similar to $B$. bassiana colony but the older the fungus the colony turned greenishwhite and finally dark green. Conidia of M. anisopliae was 6.42-6.76 $\mu \mathrm{m}$ in size. The found characteristics of the colony and conidia of $M$. anisopliae were the same as those described by Lopes et al. (2018) and Thaochan and SausaArd (2017) stating that the colony is more than 5 days old, the conidia changes from white to green indicating that the conidia were matured with the conidial mass bluish olive and have cylindrical, single and one-celled, hyaline conidia.

The result of BLAST search revealed that BKbTp showed $99.38 \%$ of similarity with $P$. citrinum strain NFML_CH33_5BbE.1 (Acc. No. KM458810.1), MSwTp1 showed $99.05 \%$ of similarity with $T$. diversus strain DTO $131 \mathrm{I} 6$ (Acc. No. KJ775700.1), BSwTd4 showed $99.65 \%$ of similarity with $B$. bassiana isolate GZMS-28 (Acc. No. KT715480.1) and MSwTp3 exhibited $99.82 \%$ of similarity with $M$. anisopliae isolate HT008 (Acc. No. MH512951.1). The result of BLAST search corresponded to those of phylogenetic tree analysis. The phylogenetic tree (Figure 3) was constructed using Mega 7 for Windows (Kumar et al. 2016) with Unweighted-pair Group Method with Arithmetic means (UPGMA). Based on the phylogenetic tree, BKbTp was placed in the group of $P$. citrinum strain NFML_CH33 5BbE.1 (Acc. No. KM458810.1), and SL1 (Acc. No. MN735924.1). MSwTp1 was in the group of $T$. diversus strain DTO_131I6 (Acc. No. KJ775700.1) and strain SCZ5-2 (Acc. No. KY445783.1). BSwTd4 was in the group of B. bassiana isolate CGAIPFBS-012 (Acc. No. KY495188.1), isolate 08F04 (Acc. No. KF359944.1), and isolate GZMS-28 (Acc. No. KT715480.1). Meanwhile, MSwTp3 was in the group of M. anisopliae HT008 (Acc. no. MH512951.1), A1 (Acc. No. KX806656.1), and IPPM010202 (Acc. No. KY437678.1). Thus, based on the morphological characters and molecular analysis, it confirmed that the identity of the four isolates was $P$. citrinum (BKbTp), T. diversus (MSwTp1), B. bassiana (BSwTd4), and M. anisopliae (MSwTp3). The isolates have been deposited in the GenBank and the accession number were MT448730 (BKbTp) (https://www.ncbi.nlm.nih.gov/nuccore/MT448730), MT448731 (MSwTp1) (https://www.ncbi.nlm.nih.gov/nuccore/MT448731), MT448732 (BSwTd4) (https://www.ncbi.nlm.nih.gov/nuccore/ MT448732), and MT448733 (MSwTp3) (https://www.ncbi.nlm.nih.gov/nuccore/MT448733). 


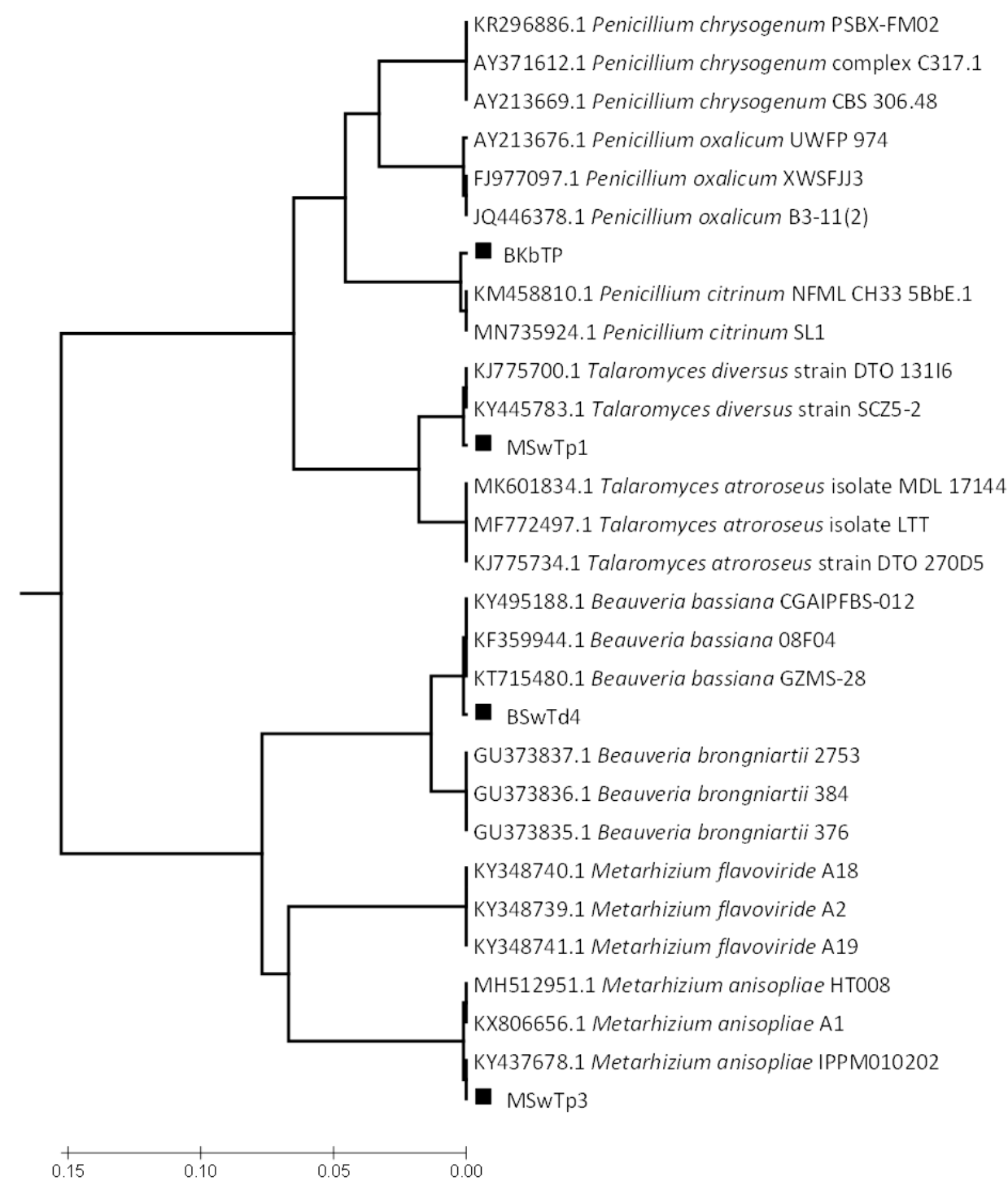

Figure 3. Dendrogram created on the basis of sequence analysis of ITS region using primer ITS1 and ITS4 with UPGMA method developed by MEGA7 for windows $\mathbf{~ = ~ f u n g a l ~ i s o l a t e s ~ u s e d ~ i n ~ t h i s ~ s t u d y ~}$

\section{EPF insecticidal activity against Spodoptera litura}

The EPF insecticidal activity against $S$. litura larvae was stated from the data of the effect of EPF on the weight reduction of edible chili leaves, bodyweight of larvae, mortality, and length of time of death. On day 1 ( 1 x 24 hours) after the larvae were treated with the filtrate culture of the EPF, the weight of the leaves eaten by S. litura larvae did not show any significant difference compared to control (sterile distilled water), but after that, the weight of the leaves eaten by the larvae was lower than control (Table 3). For the larvae treated with conidia of the EPF on day 1 ( 1 x 24 hours) and day 2 ( $2 \times 24$ hours), the weight of the eaten leaves did not show any significant difference compared to control, on the following day the weight of the eaten leaves by the larvae was significantly lower than those of the control.

The symptoms of leaves infested with larvae treated with filtrate or conidia culture showed less damage, whereas, the control leaves left only the bone of the leaf (Figures 4 and 5). The decreased appetite in leaves treated with the culture filtrate of the EPF was faster than in leaves treated with the conidia of the EPF. All tested species of the EPF significantly reduced the weight of leaves eaten by larvae compared to controls (Table 3). Thus, all species of the EPF ( $P$. citrinum, $T$. diversus, B. bassiana, and $M$. anisopliae) were effective in reducing the appetite of $S$. litura larvae. 
Tab̆le 3. Mean of leaf weight eaten by Spodoptera litura larvae treated with culture filtrates and conidia of mycoinsecticides from Penicillium citrinum, Talaromyces diversus, Beauveria Table 3. Mean of leaf weight eaten
bassiana, and Metarhizium anisopliae

\begin{tabular}{|c|c|c|c|c|c|c|c|c|c|c|c|c|}
\hline \multirow{2}{*}{ Fungal species } & \multicolumn{12}{|c|}{ Leaf weight ate by a larva $\left(\mathrm{g} \mathrm{day}^{-1}\right)$ on observation for 12 days } \\
\hline & 1 & 2 & 3 & 4 & 5 & 6 & 7 & 8 & 9 & 10 & 11 & 12 \\
\hline \multicolumn{13}{|l|}{ Culture filtrate } \\
\hline P. citrinum & 0.10 & $0.26 \mathrm{a}$ & $0.40 \mathrm{a}$ & $0.51 \mathrm{a}$ & $0.62 \mathrm{a}$ & $0.73 \mathrm{a}$ & $0.82 \mathrm{a}$ & $0.96 \mathrm{a}$ & $1.08 \mathrm{a}$ & $1.17 \mathrm{a}$ & $1.22 \mathrm{a}$ & $1.24 \mathrm{a}$ \\
\hline T. diversus & 0.14 & $0.35 \mathrm{a}$ & $0.46 \mathrm{a}$ & $0.55 \mathrm{a}$ & $0.65 \mathrm{a}$ & $0.77 \mathrm{a}$ & $0.86 \mathrm{a}$ & $0.99 \mathrm{a}$ & $1.09 \mathrm{a}$ & $1.18 \mathrm{a}$ & $1.23 \mathrm{a}$ & $1.25 \mathrm{a}$ \\
\hline B. bassiana & 0.17 & $0.36 \mathrm{a}$ & $0.47 \mathrm{a}$ & $0.58 \mathrm{a}$ & $0.74 \mathrm{a}$ & $0.94 \mathrm{a}$ & $1.08 \mathrm{a}$ & $1.22 \mathrm{a}$ & $1.35 \mathrm{ab}$ & $1.45 \mathrm{ab}$ & $1.53 \mathrm{ab}$ & $1.59 \mathrm{~b}$ \\
\hline M. anisopliae & 0.17 & $0.36 \mathrm{ab}$ & $0.53 \mathrm{a}$ & $0.65 \mathrm{a}$ & $0.78 \mathrm{a}$ & $0.97 \mathrm{a}$ & $1.11 \mathrm{a}$ & $1.26 \mathrm{a}$ & $1.42 \mathrm{~b}$ & $1.55 \mathrm{~b}$ & $1.65 \mathrm{ab}$ & $1.77 \mathrm{~b}$ \\
\hline Control & 0.24 & $0.56 \mathrm{~b}$ & $0.94 \mathrm{~b}$ & $1.32 \mathrm{~b}$ & $1.74 \mathrm{~b}$ & $2.33 \mathrm{~b}$ & $2.91 \mathrm{~b}$ & $3.45 \mathrm{~b}$ & $4.02 \mathrm{c}$ & $4.65 \mathrm{c}$ & $5.04 \mathrm{c}$ & $5.58 \mathrm{c}$ \\
\hline F-value & $1.96^{\mathrm{ns}}$ & $6.86^{*}$ & $10.28^{*}$ & $19.63^{*}$ & $44.96^{*}$ & $76.82 *$ & $124.79 *$ & $131.90^{*}$ & $203.70^{*}$ & $263.92 *$ & $281.95^{*}$ & $324.89^{*}$ \\
\hline P-value & 0.19 & 0.011 & 0.0031 & 0.00034 & 0.000016 & 0.0000020 & 0.00000031 & 0.00000025 & 0.000000044 & 0.000000016 & 0.000000012 & 0.0000070 \\
\hline HSD value & - & 0.10 & 0.14 & 0.15 & 0.12 & 0.12 & 0.12 & 0.13 & 0.117 & 0.115 & 0.119 & 0.122 \\
\hline \multicolumn{13}{|l|}{ Conidia } \\
\hline P. citrinum & 0.45 & 0.76 & $1.13 \mathrm{a}$ & $1.50 \mathrm{a}$ & $1.84 \mathrm{a}$ & $2.00 \mathrm{a}$ & $2.28 \mathrm{a}$ & $2.47 \mathrm{a}$ & $2.62 \mathrm{a}$ & $2.74 \mathrm{a}$ & $2.85 \mathrm{a}$ & $2.92 \mathrm{a}$ \\
\hline T. diversus & 0.45 & 0.84 & $1.17 \mathrm{a}$ & $1.50 \mathrm{a}$ & $1.87 \mathrm{a}$ & $2.15 \mathrm{a}$ & $2.51 \mathrm{a}$ & $2.71 \mathrm{a}$ & $2.94 \mathrm{a}$ & $3.04 \mathrm{a}$ & $3.19 \mathrm{a}$ & $3.28 \mathrm{a}$ \\
\hline B. bassiana & 0.44 & 0.76 & $1.09 \mathrm{a}$ & $1.43 \mathrm{a}$ & $1.76 \mathrm{a}$ & $2.07 \mathrm{a}$ & $2.40 \mathrm{a}$ & $2.59 \mathrm{a}$ & $2.87 \mathrm{a}$ & $3.01 \mathrm{a}$ & $3.21 \mathrm{a}$ & $3.45 \mathrm{a}$ \\
\hline M. anisopliae & 0.34 & 0.70 & $1.08 \mathrm{a}$ & $1.39 \mathrm{a}$ & $1.78 \mathrm{a}$ & $2.10 \mathrm{a}$ & $2.35 \mathrm{a}$ & $2.54 \mathrm{a}$ & $2.72 \mathrm{a}$ & $2.86 \mathrm{a}$ & $3.01 \mathrm{a}$ & $3.23 \mathrm{a}$ \\
\hline Control & 0.56 & 1.28 & $1.97 \mathrm{~b}$ & $2.64 \mathrm{~b}$ & $3.33 \mathrm{~b}$ & $3.99 \mathrm{~b}$ & $4.99 \mathrm{~b}$ & $5.73 \mathrm{~b}$ & $6.57 \mathrm{~b}$ & $7.49 \mathrm{~b}$ & $8.32 \mathrm{~b}$ & $9.16 \mathrm{~b}$ \\
\hline F-value & $1.78^{\mathrm{ns}}$ & $3.58^{\text {ns }}$ & $7.14 *$ & 18.26 * & $16.06 *$ & $17.38 *$ & $14.98 *$ & $14.07 *$ & $17.72 *$ & 23.27 * & $26.81 *$ & $33.23 *$ \\
\hline$P$ value & 0.23 & 0.06 & 0.01 & 0.0004 & 0.0007 & 0.0005 & 0.001 & 0.0011 & 0.0005 & 0.0002 & 0.0001 & 0.00005 \\
\hline HSD value & & & 0.23 & 0.18 & 0.23 & 0.26 & 0.35 & 0.41 & 0.42 & 0.42 & 0.43 & 0.42 \\
\hline
\end{tabular}

Note: ns = not significantly different; * = significantly different; values within a column followed by the same letters were not significantly different at P $<0.05$ according to Tukey's HSD test

Table 4. Mean of larvae weight of Spodoptera litura treated with culture filtrates and conidia of mycoinsecticides from Penicillium citrinum, Talaromyces diversus, Beauveria bassiana, and Metarhizium anisopliae

\begin{tabular}{|c|c|c|c|c|c|c|c|c|c|c|c|c|}
\hline \multirow{2}{*}{ Fungal species } & \multicolumn{12}{|c|}{ Weight of larvae ( g larvae $^{-1}$ ) on observation for 12 days } \\
\hline & 1 & 2 & 3 & 4 & 5 & 6 & 7 & 8 & 9 & 10 & 11 & 12 \\
\hline \multicolumn{13}{|l|}{ Culture filtrate } \\
\hline P. citrinum & 0.06 & $0.09 \mathrm{a}$ & $0.12 \mathrm{a}$ & $0.15 \mathrm{a}$ & $0.19 \mathrm{a}$ & $0.22 \mathrm{a}$ & $0.25 \mathrm{a}$ & $0.29 \mathrm{a}$ & $0.34 \mathrm{ab}$ & $0.40 \mathrm{a}$ & $0.48 \mathrm{ab}$ & $0.50 \mathrm{a}$ \\
\hline T. diversus & 0.06 & $0.09 \mathrm{a}$ & $0.12 \mathrm{a}$ & $0.15 \mathrm{a}$ & $0.18 \mathrm{a}$ & $0.22 \mathrm{a}$ & $0.27 \mathrm{a}$ & $0.31 \mathrm{a}$ & $0.38 \mathrm{~b}$ & $0.46 \mathrm{~b}$ & $0.53 \mathrm{~b}$ & $0.58 \mathrm{~b}$ \\
\hline B. bassiana & 0.06 & $0.09 \mathrm{a}$ & $0.12 \mathrm{a}$ & $0.15 \mathrm{a}$ & $0.18 \mathrm{a}$ & $0.21 \mathrm{a}$ & $0.25 \mathrm{a}$ & $0.29 \mathrm{a}$ & $0.33 \mathrm{a}$ & $0.39 \mathrm{a}$ & $0.45 \mathrm{a}$ & $0.51 \mathrm{a}$ \\
\hline M. anisopliae & 0.06 & $0.09 \mathrm{a}$ & $0.12 \mathrm{a}$ & $0.15 \mathrm{a}$ & $0.18 \mathrm{a}$ & $0.22 \mathrm{a}$ & $0.26 \mathrm{a}$ & $0.31 \mathrm{a}$ & $0.36 \mathrm{ab}$ & $0.41 \mathrm{ab}$ & $0.47 \mathrm{a}$ & $0.53 \mathrm{ab}$ \\
\hline Control & 0.07 & $0.11 \mathrm{~b}$ & $0.16 \mathrm{~b}$ & $0.21 \mathrm{~b}$ & $0.28 \mathrm{~b}$ & $0.34 \mathrm{~b}$ & $0.42 \mathrm{~b}$ & $0.50 \mathrm{~b}$ & $0.58 \mathrm{c}$ & $0.68 \mathrm{c}$ & $0.78 \mathrm{c}$ & $0.89 \mathrm{c}$ \\
\hline F-value & $2.91^{\mathrm{ns}}$ & $6.31 *$ & $12.24 *$ & $1.07 *$ & $36.38^{*}$ & $52.94 *$ & $74.25 *$ & $109.18^{*}$ & $97.99^{*}$ & $96.07^{*}$ & 107.63 * & $40.12 *$ \\
\hline P-value & 0.09 & 0.014 & 0.0017 & 0.00026 & 0.000035 & 0.0000085 & 0.0000023 & 0.00000052 & 0.00000079 & 0.00000085 & 0.00000055 & 0.000024 \\
\hline HSD value & - & 0.01 & 0.01 & 0.02 & 0.02 & 0.02 & 0.02 & 0.02 & 0.024 & 0.03 & 0.028 & 0.053 \\
\hline \multicolumn{13}{|l|}{ Conidia } \\
\hline P. citrinum & 0.12 & $0.18 \mathrm{ab}$ & $0.23 \mathrm{a}$ & $0.29 \mathrm{a}$ & $0.35 \mathrm{a}$ & $0.41 \mathrm{a}$ & $0.47 \mathrm{a}$ & $0.53 \mathrm{a}$ & $0.59 \mathrm{a}$ & $0.65 \mathrm{a}$ & $0.73 \mathrm{a}$ & $0.75 \mathrm{a}$ \\
\hline T. diversus & 0.13 & $0.19 a b$ & $0.25 \mathrm{ab}$ & $0.32 \mathrm{a}$ & $0.39 \mathrm{a}$ & $0.46 \mathrm{a}$ & $0.52 \mathrm{a}$ & $0.59 \mathrm{a}$ & $0.66 \mathrm{a}$ & $0.74 \mathrm{a}$ & $0.83 \mathrm{a}$ & $0.85 \mathrm{a}$ \\
\hline B. bassiana & 0.11 & $0.17 \mathrm{a}$ & $0.24 \mathrm{a}$ & $0.31 \mathrm{a}$ & $0.38 \mathrm{a}$ & $0.45 \mathrm{a}$ & $0.50 \mathrm{a}$ & $0.57 \mathrm{a}$ & $0.64 \mathrm{a}$ & $0.72 \mathrm{a}$ & $0.81 \mathrm{a}$ & $0.90 \mathrm{a}$ \\
\hline M. anisopliae & 0.12 & $0.18 \mathrm{ab}$ & $0.25 \mathrm{ab}$ & $0.31 \mathrm{a}$ & $0.38 \mathrm{a}$ & $0.45 \mathrm{a}$ & $0.52 \mathrm{a}$ & $0.59 \mathrm{a}$ & $0.66 \mathrm{a}$ & $0.74 \mathrm{a}$ & $0.82 \mathrm{a}$ & $0.91 \mathrm{a}$ \\
\hline Control & 0.12 & $0.20 \mathrm{~b}$ & $0.27 \mathrm{~b}$ & $0.36 \mathrm{~b}$ & $0.45 \mathrm{~b}$ & $0.55 \mathrm{~b}$ & $0.65 \mathrm{~b}$ & $0.77 \mathrm{~b}$ & $0.90 \mathrm{~b}$ & $1.03 \mathrm{~b}$ & $1.18 \mathrm{~b}$ & $1.33 \mathrm{~b}$ \\
\hline F-value & $3.37^{\mathrm{ns}}$ & $4.07 *$ & $6.49^{*}$ & $7.49^{*}$ & $9.23^{*}$ & $12.46^{*}$ & $15.82 *$ & $20.61^{*}$ & $27.40^{*}$ & $32.25^{*}$ & $36.85^{*}$ & $64.25^{*}$ \\
\hline $\mathrm{P}$ value & 0.07 & 0.04 & 0.01 & 0.01 & 0.004 & 0.002 & 0.001 & 0.0003 & 0.0001 & 0.00006 & 0.00003 & 0.000004 \\
\hline HSD value & - & 0.01 & 0.01 & 0.02 & 0.028 & 0.03 & 0.04 & 0.04 & 0.05 & 0.05 & 0.05 & 0.05 \\
\hline
\end{tabular}




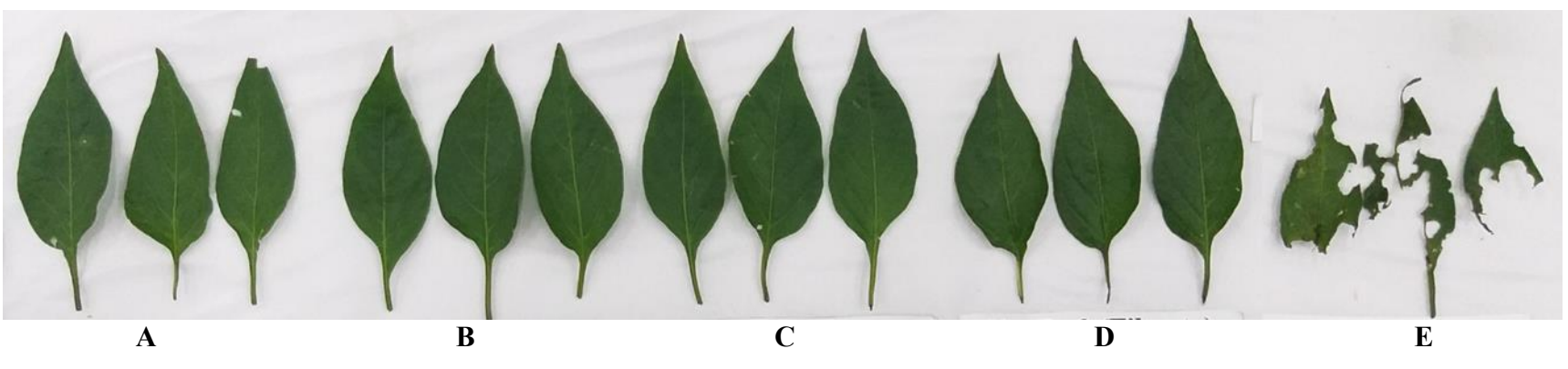

Figure 4. The symptoms on chili leaves eaten by Spodoptera litura larvae treated with culture filtrates of mycoinsecticides and control. Note: A. BKbTp (Filtrate), B. BSwTd4 (Filtrate), C. MSwTp1 (Filtrate), MSwTp3 (Filtrate), E. Control. Bar $=2 \mathrm{~cm}$

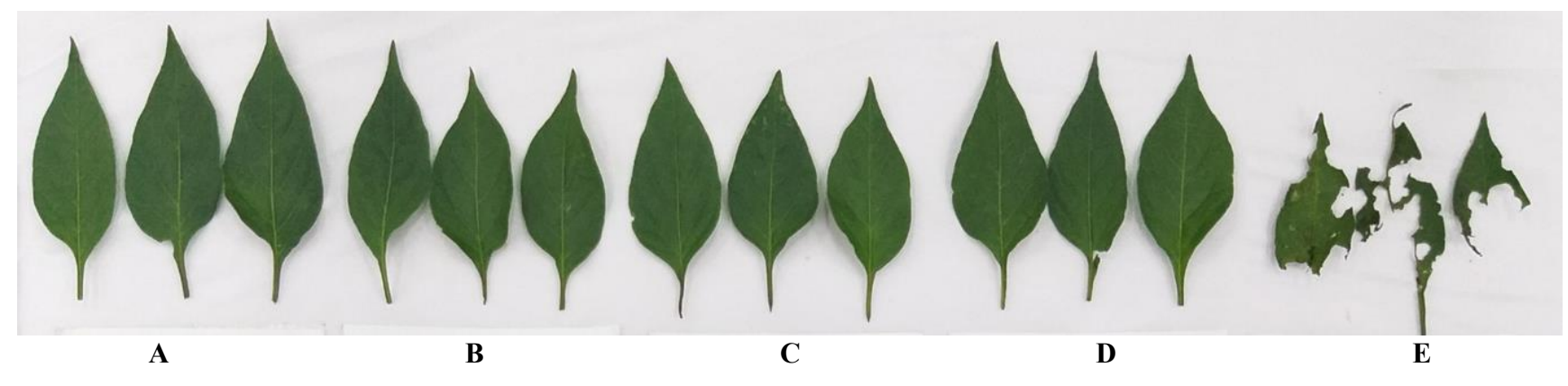

Figure 5. The symptoms on chili leaves eaten by Spodoptera litura larvae treated with conidia of mycoinsecticides and control. Note: A. BKbTp (Filtrate), B. BSwTd4 (Filtrate), C. MSwTp1 (Filtrate), MSwTp3 (Filtrate), E. Control. Bar = $2 \mathrm{~cm}$

The decreased appetite of S. litura larvae treated with culture filtrate or conidia EPF was one of the stages of the larvae to be ill due to the treatment with EPF. In culture filtrate experiments, the larvae appetite already decreased on $2^{\text {nd }}$ day and was faster on day $1^{\text {st }}$ than the trial using the EPF conidia. In culture filtrate experiments, the decreased appetite was faster due to the raw secondary metabolite content of larvae consumed from the first day since the EPF culture filtrate was exposed, whereas in conidia treatment it required conidia time to enter the hemolymph and secrete secondary metabolites. The process of being ill due to the EPF started with the conidia attached to the cuticle larvae, and then the conidia rupture to form germ tubes to penetrate the cuticle (Fernandes et al. 2007). The infection started when germ tubes were able to penetrate the insect cuticle and the ability to infect was a determinant of the level of virulence EPF (Altre and Vandenberg 2001). After germ tubes reach the hemocoel, they produced specific infection hyphae originating at appressoria (ElGhany 2015). Then the hyphae spread to the hemolymph and developed to produce blastospores. The blastospores then produced the secondary metabolites and enzymes that could disrupt normal cell metabolism (Mancillas-Paredes et al. 2019). The penetration stages of germ tubes to blastospores produced secondary metabolites and the enzymes occurred in the experiments using conidia, whereas in culture filtrate experiments this stage did not occur because the two stages of filtration were already carried out to separate conidia from the filtrate. Therefore, the process of the larvae starting to be ill in the culture filtrate was faster than the conidia experiment. In the next process, the toxins from secondary metabolites began to kill the host insect but the death of the host insect was not only by the toxin but also by the mechanical damage of the fungal penetration into the body of the insect (El-Ghany 2015).

The reduction of the weight of the eaten affected the weight of the larvae. At 1 x 24 hours after the larvae were treated with culture filtrate or EPF conidia, the weight of the $S$. litura larvae did not show any significant difference, starting on the second day the larvae weight began to be lower than that of the control (Table 4), as well as the third day up to the 12 days the larvae weight was lower than that of the control. All the tested species of the EPF decreased significantly the larvae body weight compared to that of the control. Consequently, the larvae treated with mycoinsecticides containing the culture filtrate or EPF conidia could reduce the larvae appetite to make their bodyweight decrease.

Percentage of the mortality or mortality of the larvae caused by the EPF culture filtrate showed significant differences when compared to that of the control (Table 5). All EPF species were toxic to $S$. litura larvae, both their culture filtrate and conidia. The highest larvae mortality due to culture filtrate was found in the treatment of $P$. citrinum (98.67\%) and not significantly different from the larvae mortality by $T$. diversus (96\%), but significantly different from the larvae mortality by $B$. bassiana $(86.67 \%)$ and $M$ anisopliae $(82.67 \%)$. The $\mathrm{LT}_{50}$ larvae treated with culture filtrate $T$. diversus was the shortest (6.19 days) and not significantly different from the LT50 larvae treated with $P$. citrinum (6.62 days), but significantly different from the $\mathrm{LT}_{50}$ larvae treated with $B$. bassiana (7.55 days) 
and $M$. anisopliae (7.60 days). Thus, the most toxic EPF species against $S$. litura larvae was $P$. citrinum. The larvae mortality due to the EPF conidia showed significant differences when compared to that of the control (Table 5). All of the EPF species were pathogenic to $S$. litura larvae. The larvae mortality caused by the conidia was highest in $P$. citrinum (98.67\%) which was not significantly different from the larvae mortality by $T$. diversus $(97.33 \%), B$. bassiana $(86.67 \%)$, and $M$. anisopliae $(86.67 \%)$. The $\mathrm{LT}_{50}$ of the larvae treated with the conidia of $P$. citrinum was the shortest (5.45 days) and not significantly different from the $\mathrm{LT}_{50}$ of larvae treated with $T$. diversus (6.55 days), but it was significantly different from the $\mathrm{LT}_{50}$ of larvae treated with $B$. bassiana (8.88 days) and $M$. anisopliae (7.70 days). Thus, the most pathogenic EPF species against $S$. litura larvae was $P$. citrinum.

Both culture filtrate and conidia of EPF in this study had significantly higher insecticidal activity than the control, and the highest insecticidal activity was found in P. citrinum. P. citrinum had the highest insecticidal activity due to its ability to infect the larvae faster shown by its $\mathrm{LT}_{50}$ value which was the shortest compared to the other species. Altre and Vandenberg (2001) state that the most pathogenic EPF species due to the fungus has germ tubes that are able to penetrate the insect cuticle faster than other fungal species and have more toxins and enzymes that disrupt normal cell metabolism in insects. In addition, the color of the $P$. citrinum culture filtrate was the darkest compared to the color of the culture filtrate of the other three EPF species. The darker color of the EPF culture filtrate proved to be more toxic than the lighter color of the culture filtrate (Ayudya et al. 2019; Gustianingtyas et al., 2020) because the darker the color of the fungus culture filtrate the higher the concentration of the secondary metabolites (Luo et al., 2017). The P. citrinum culture filtrate contains secondary metabolites and is toxic to insects, for example, patulin which can kill Culex quinquefasciatus larvae up to $100 \%$ (Maketon et al. 2014). $P$. citrinum is reported to be effective in killing insect pests (Foo et al. 2017; Maketon et al. 2014) and mite pests (Mazid et al. 2016).

The other EPF species were also toxic because they had enzymes or secondary metabolites that could kill the host insects, for example, $B$. bassiana produced the enzymes of proteolytic and chitinolytic that could disrupt normal cell metabolism (Mancillas-Paredes et al. 2019). The secondary metabolite produced by $B$. bassiana containing the bassianolone B toxic to the T. molitor larvae (Luo et al. 2017). M. anisopliae produces secondary metabolites, including destruxins toxic to insect pests (Borisade et al. 2016). So far there has been no information on the secondary metabolites or enzymes produced by $T$. diversus that kills insects. At present, there is only general information stating that $T$. diversus can kill insects (Visagie et al. 2009). For this reason, in the future, it is necessary to study to identify the secondary metabolites or $T$. diversus enzymes that can kill insect pests.
Table 5. Mean of larvae mortality and $\mathrm{LT}_{50}$ of Spodoptera litura larvae treated with culture filtrates and conidia of mycoinsecticides from Penicillium citrinum, Talaromyces diversus, Beauveria bassiana, and Metarhizium anisopliae

\begin{tabular}{lrr}
\hline Fungal species & $\begin{array}{r}\text { Mortality } \pm \text { SE } \\
(\%)\end{array}$ & $\mathbf{L T}_{\mathbf{5 0}} \pm \mathbf{S E}$ (days) \\
\hline Culture filtrate & $98.67 \pm 1.09 \mathrm{c}$ & $6.62 \pm 0.135 \mathrm{a}$ \\
$P$. citrinum & $96.00 \pm 1.89 \mathrm{c}$ & $6.19 \pm 0.072 \mathrm{a}$ \\
T. diversus & $86.67 \pm 2.88 \mathrm{~b}$ & $7.55 \pm 0.154 \mathrm{a}$ \\
B. bassiana & $82.67 \pm 1.09 \mathrm{~b}$ & $7.60 \pm 0.203 \mathrm{~b}$ \\
M. anisopliae & $0.00 \pm 0.00 \mathrm{a}$ & - \\
Control & $187.26^{*}$ & $13.12^{*}$ \\
F-value & 0.0000006 & 0.00480044 \\
P-value & 11.38 & 0.87 \\
HSD value & & \\
Conidia & $98.67 \pm 1.09 \mathrm{~b}$ & $5.45 \pm 0.232 \mathrm{a}$ \\
$P$. citrinum & $97.33 \pm 2.18 \mathrm{~b}$ & $6.55 \pm 0.081 \mathrm{ab}$ \\
$T$. diversus & $86.67 \pm 1.09 \mathrm{~b}$ & $8.88 \pm 0.420 \mathrm{c}$ \\
B. bassiana & $86.67 \pm 1.09 \mathrm{~b}$ & $7.70 \pm 0.404 \mathrm{bc}$ \\
$M$. anisopliae & $0.00 \pm 0.00 \mathrm{a}$ & - \\
Control & $156.31^{*}$ & $29.38^{*}$ \\
F-value & 0.0000013 & 0.00055 \\
P-value & 12.70 & 1.24 \\
HSD value &
\end{tabular}

Note: * = significantly different; values within a column followed by the same letters were not significantly different at $\mathrm{P}<0.05$ according to Tukey's HSD test.

The $S$. litura larvae treated with EPF culture or conidia showed the same behavior, i.e., they ate less and less and got lazy to move, while the control not treated with the EPF continued to eat greedily and actively moved. After 3 days the larvae given culture filtrate began to change integument color that was previously bright green to dull and began to find dead larvae and the same symptoms occurred in larvae treated with EPF conidia. Four days after the larvae were treated with culture filtrate or EPF conidia, the larvae's body began to shrink, wrinkle, get odorless and dull black, and eventually died (Figure 6 and 7). After 2-3 days the larvae died, the symptoms in the larvae integument died due to the conidia covered by mycelia and the conidia appeared, whereas in larvae that died due to the culture filtrate there was no mycelia and conidia.

Thus, the symptoms of ill $S$. litura larvae caused by the culture filtrate were slightly different from the symptoms caused by the EPF conidia. The symptoms of sick larvae due to the culture of this filtrate were the same as the symptoms described by Ayudya et al. (2019) and Gustianingtyas et al. (2020), namely the larvae got shrunk, wrinkled, dry, odorless, and the integument was not covered by EPF conidia. The symptoms of sick insects caused by EPF conidia in this study were the same as those described by Bugti et al. (2018) and Sumikarsih et al. (2019), that is, the insect's body got smaller, wrinkled, dry, odorless, and the integument was covered in mycelia and EPF conidia. 


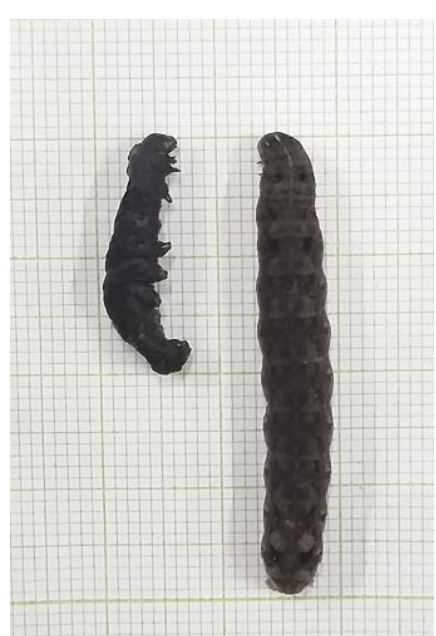

A

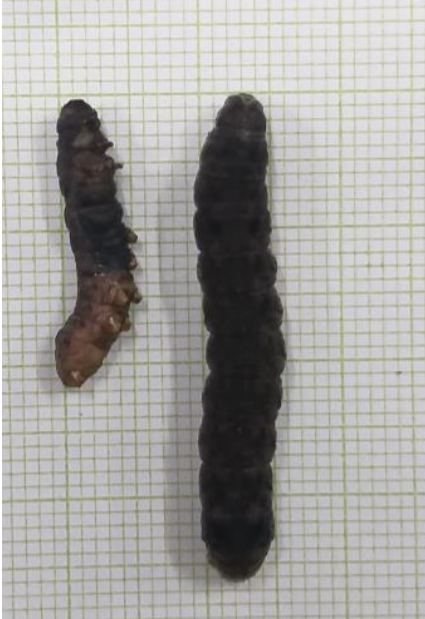

B

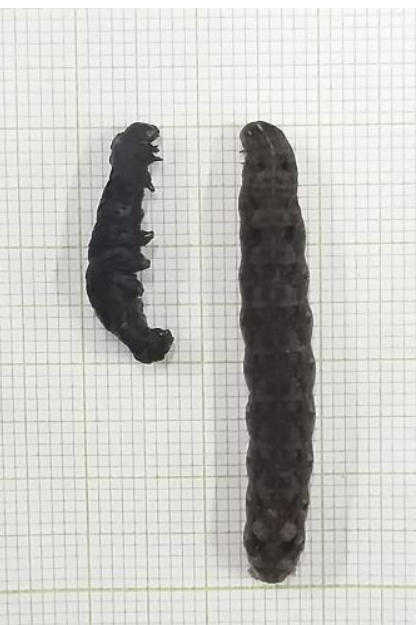

C

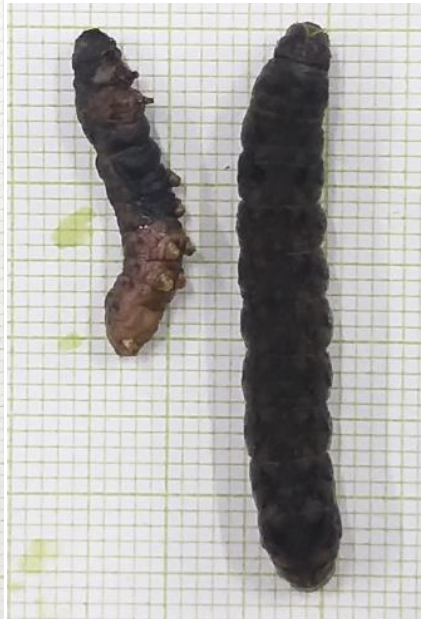

D

Figure 6. Morphology of Spodoptera litura larvae of healthy larvae of control (right) and dead larvae (left) treated with culture filtrate of mycoinsecticides from Penicillium citrinum (A), Talaromyces diversus (B), Beauveria bassiana (C), and Metarhizium anisopliae (D)

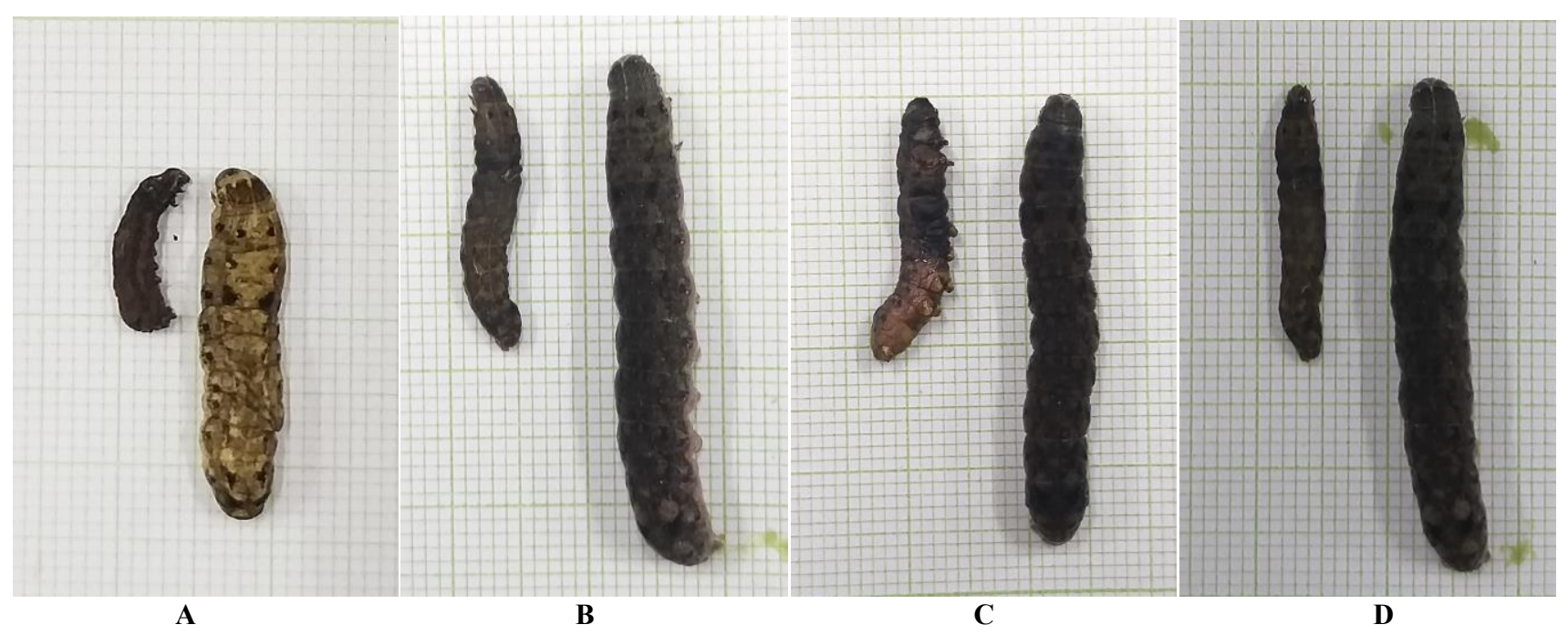

Figure 7. Morphology of Spodoptera litura larvae of healthy larvae of control (right) and dead larvae (left) treated with conidia of mycoinsecticides from Penicillium citrinum (A), Talaromyces diversus (B), Beauveria bassiana (C), and Metarhizium anisopliae (D)

The results of bioassays of culture filtrate and EPF conidia showed that both culture filtrate and conidia had high insecticidal activity. However, for the future development of mycoinsecticides, the use of culture filtrate without conidia as the active ingredient of mycoinsecticide needs to be further investigated. The fungus culture filtrate is relatively more stable than the culture that still has conidia and can be stored for a longer time and remains toxic, besides the culture filtrate does not clog the sprayer nozzle when sprayed (Soesanto et al. 2019).

The conclusion of this research is that the EPF species found in the soils of South Sumatra were P. citrinum, $T$. diversus, $B$. bassiana, and $M$. anisopliae. All species have a high insecticidal activity against $S$. litura larvae and the most toxic species is $P$. citrinum. The filtrate and conidia of the $P$. citrinum are toxic. $P$. citrinum, a new emerging entomopathogenic fungus, has the highest insecticidal activity and the highest potential to be developed into commercial mycoinsecticides.

\section{ACKNOWLEDGEMENTS}

This research was funded by the scheme of Applied Research (Riset Terapan) with budget year of 2020 according to Directorate of Research and Community Service (Direktorat Riset dan Pengabdian Masyarakat), Ministry of Research and Technology/National Research and Innovation Agency of Republic Indonesia, Grant/Contract Number: SP DIPA-042.06.1.401516/2020. 


\section{REFERENCES}

Alhusein N, Scott J, Kasprzyk-Hordern B, Bolhuis A. 2016. Development of a filter to prevent infections with spore-forming bacteria in injecting drug users. Harm Reduct J 13: 1-8. DOI: 10.1186/s12954016-0122-1.

Altre JA, Vandenberg JD. 2001. Factors influencing the infectivity of isolates of Paecilomyces fumosoroseus against diamondback moth, Plutella xylostella. J Invertebr Pathol 78: 31-36. DOI: 10.1006/jipa.2001.5043.

Anwar W, Khan SN, Aslam M, Haider MS, Shahid AA, Ali M. 2015. Exploring fungal flora associated with insects of cotton agroecological zones of Punjab, Pakistan. Pakistan Entomol 37: 27 31.

Ayudya DR, Herlinda S, Suwandi S. 2019. Insecticidal activity of culture filtrates from liquid medium of Beauveria bassiana isolates from South Sumatra (Indonesia) wetland soil against larvae of Spodoptera litura. Biodiversitas 20: 2101-2109. DOI: 10.13057/biodiv/d200802.

Borisade OA, Medina A, Magan N. 2016. Interacting temperature and water activity modulate production of destruxin a by Metarhizium anisopliae on galleria larvae-modified agar-based media invitro. West African J Appl Ecol 24: 31-42.

Bugti GA, Bin W, Na C, Feng LH. 2018. Pathogenicity of Beauveria bassiana strain 202 against sap-sucking insect pests. Plant Prot Sci 54: 111-117. DOI: 10.17221/45/2017-PPS.

Chen Z, Xu L, Yang F, Ji G, Yang J, Wang J. 2014. Efficacy of Metarhizium anisopliae isolate MAX-2 from Shangri-la, China under desiccation stress. BMC Microbiol 14: 4. DOI: 10.1186/1471-218014-4.

El-Ghany TMA. 2015. Entomopathogenic Fungi and their Role in Biological Control. Biology Department, Faculty of Science Jazan University KSA, Cairo. DOI: 10.4172/978-1-63278-065-2-66.

Fernandes EKK, Rangel DEN, Moraes AM, Bittencourt VREP, Roberts DW. 2007. Variability intolerance to UV-B radiation among Beauveria spp. isolates. J Invertebr Pathol 96: 237-243. DOI: 10.1016/j.jip.2007.05.007.

Foo K, Seelan JSS, Dawood MM. 2017. Microfungi associated with Pteroptyx bearni (Coleoptera: Lampyridae) eggs and larvae from Kawang River, Sabah (Northern Borneo). Insects 8: 1-12. DOI: 10.3390/insects8030066.

Gustianingtyas M, Herlinda S, Suwandi, Suparman, Hamidson H, Hasbi, Setiawan A, Verawaty M, Elfita, Arsi. 2020. Toxicity of entomopathogenic fungal culture filtrate of lowland and highland soil of South Sumatra (Indonesia) against Spodoptera litura larvae. Biodiversitas 21: 1839-1849. DOI: 10.13057/biodiv/d210510.

Hernandez-Trejo A, Estrada-Drouaillet B, López-Santillán, J, RiosVelasco C, Varela-Fuentes S, Rodríguez-Herrera R, OsorioHernández E. 2019. In vitro evaluation of native entomopathogenic fungi and neem (Azadiractha indica) extracts on Spodoptera frugiperda. Intl J Exp Bot 4: 75-84. DOI: 10.1037//00332909.I26.1.78.

Johari A, Herlinda S, Irsan C, Pujiastuti Y. 2016. Phenomenon of Thrips (Thysanoptera) attack on chili plant (Capsicum annuum). Am J Agric Biol Sci 11: 103-109. DOI: 10.3844/ajabssp.2016.103.109.

Kumar S, Stecher G, Tamura K. 2016. MEGA7: Molecular evolutionary genetics analysis version 7.0 for bigger data sets. Mol Biol Evol 33: 1870-1874. DOI: $10.1093 / \mathrm{molbev} / \mathrm{msw} 054$.

Liu SF, Wang GJ, Nong XQ, Liu B, Wang MM, Li SL, Cao GC, Zhang ZH. 2017. Entomopathogen Metarhizium anisopliae promotes the early development of peanut root. Plant Prot Sci 53: 101-107. DOI: 10.17221/49/2016-PPS.

Lopes RB, Souza DA, Rocha LFN, Montalva C, Luz C, Humber RA, Faria M. 2018. Metarhizium alvesii sp. nov.: A new member of the Metarhizium anisopliae species complex. J Invertebr Pathol 151: 165168. DOI: 10.1016/j.jip.2017.12.001.

Luo Z, Ren H, Mousa JJ, Rangel DEN, Zhang Y, Bruner SD, Keyhani NO. 2017. The PacC transcription factor regulates secondary metabolite production and stress response, but has only minor effects on virulence in the insect pathogenic fungus Beauveria bassiana. Environ Microbiol 19: 788-802. DOI: 10.1111/1462-2920.13648.

Maketon M, Amnuaykanjanasin A, Kaysorngup A. 2014. A rapid knockdown effect of Penicillium citrinum for control of the mosquito Culex quinquefasciatus in Thailand. World J Microbiol Biotechnol 30: 727-736. DOI: 10.1007/s11274-013-1500-4.
Mancillas-Paredes J, Hernández-Sánchez H, Jaramillo-Flores ME, GarcíaGutiérrez C. 2019. Proteases and chitinases induced in Beauveria bassiana during infection by Zabrotes subfasciatus. Southwest. Entomol 44: 125-137. DOI: 10.3958/059.044.0114.

Mascarin GM, Jackson MA, Kobori NN, Behle RW, Delalibera Júnior Í. 2015. Liquid culture fermentation for rapid production of desiccationtolerant blastospores of Beauveria bassiana and Isaria fumosorosea strains. J Invertebr Pathol 127: 11-20. DOI: 10.1016/j.jip.2014.12.001.

Mathew AJ, Jayachandran K, Mathew J. 2010. Endophytic Penicillium citrinum Thom. from Scoparia dulcis Linn. Indian J Microbiol 50: 99-102. DOI: 10.1007/s12088-010-0065-2.

Mazid S, Kalita JC, Rajkhowa RC. 2016. Biocontrol potential of Penicillium citrinum and Penicillium chrysogenum against red spider mite, Oligonychus coffeae Nietner infesting tea. J Entomol Res DOI: 10.5958/0974-4576.2016.00008.6.

Ngangambe MH, Mwatawala MW. 2020. Effects of entomopathogenic fungi (EPFs) and cropping systems on parasitoids of fall armyworm (Spodoptera frugiperda) on maize in eastern central, Tanzania. $\begin{array}{lllll}\text { Biocontrol Sci } & \text { Technol } & 30: & 1-13 . & \text { DOI: }\end{array}$ 10.1080/09583157.2020.1726878.

Safitri A, Herlinda S, Setiawan A. 2018. Entomopathogenic fungi of soils of freshwater swamps, tidal lowlands, peatlands, and highlands of South Sumatra, Indonesia. Biodiversitas 19: 2365-2373. DOI: 10.13057/biodiv/d190647.

Sharma L, Oliveira I, Torres L, Marques G. 2018. Entomopathogenic fungi in Portuguese vineyards soils: suggesting a 'Galleria-Tenebriobait method' as bait-insects Galleria and Tenebrio significantly underestimate the respective recoveries of Metarhizium (robertsii) and Beauveria (bassiana). MycoKeys 23: 1-23. DOI: 10.3897/mycokeys.38.26970.

Siaga E, Lakitan B, Hasbi H, Bernas SM, Widuri LI, Kartika K. 2019. Floating seedbed for preparing rice seedlings under unpredictable flooding occurrence at tropical riparian wetland. Bulg J Agric Sci 25: 326-336.

Soesanto L, Mugiastuti E, Manan A. 2019. Raw secondary metabolites application of two Trichoderma harzianum isolates towards vascular streak dieback on cocoa seedlings. Pelita Perkebunan 35: 22-32. DOI: 10.22302/iccri.jur.pelitaperkebunan.v35i1.346.

Souza ML, Sanches MM, Souza DAde, Faria M, Espinel-Correal C, Sihler W, Lopes RB. 2019. Within-host interactions of Metarhizium rileyi strains and nucleopolyhedroviruses in Spodoptera frugiperda and Anticarsia gemmatalis (Lepidoptera: Noctuidae). J Invertebr Pathol 162: 10-18. DOI: 10.1016/j.jip.2019.01.006

Sowmya G, Ramanagouda SH, Jayappa J. 2017. Lethal and sub-lethal effects of indigenous isolates of Metarhizium anisopliae (Metchnikoff) Sorokin against Spodoptera litura (Fabricius). Entomol Zool Stud 5: 1154-1160.

Sumikarsih E, Herlinda S, Pujiastuti Y. 2019. Conidial density and viability of Beauveria bassiana isolate from Java and Sumatra and their virulence against Nilaparvata lugens at different temperatures. Agrivita J Agric Sci 41: 335-349. DOI: 10.17503/agrivita.v41i2.2105.

Suwandi, Ammar M, Chandra I. 2012. Application of extract compost increased yield and suppressed the diseases of ratoon rice crop in tidal swamp of Banyuasin Regency. J Suboptimal Lands 1: 116-122. DOI: 10.33230/JLSO.1.2.2012.15. [Indonesian]

Syamsudin TS, Faizal A, Kirana, R. 2019. Dataset on antixenosis and antibiosis of chili fruit by fruit fly (Bactrocera dorsalis) infestation Data Brief 23:103758. DOI: 10.1016/j.dib.2019.103758.

Thaochan N, Sausa-Ard W. 2017. Occurrence and effectiveness of indigenous Metarhizium anisopliae against adults Zeugodacus cucurbitae (Coquillett) (Diptera: Tephritidae) in Southern Thailand. Songklanakarin J Sci Technol 39: 325-334. DOI: 10.14456/sjstpsu.2017.35.

Tompe AA, Hole UB, Kulkarni SR, Chaudhari CS, Chavan SK. 2020. Studies on seasonal incidence of leaf-eating caterpillar, Spodoptera litura (Fab.) infesting capsicum under polyhouse condition. J Entomol Zool Stud 8: 761-764.

Vijayalakshmi P, Vijayalakshmi T, Naidu LN. 2016. Evaluation of certain insecticide molecules against chillipod borer, Spodoptera litura in Andhra Pradesh. J Res ANGRAU 44: 26-30.

Visagie CM, Jacobs K. 2012. Three new additions to the genus Talaromyces isolated from Atlantis sandveld fynbos soils. Persoonia 28: 14-24. DOI: $10.3767 / 003158512 X 632455$. 
Visagie CM, Roets F, Jacobs K. 2009. A new species of Penicillium, $P$. ramulosum sp. nov., from the natural environment. Mycologia 101: 888-895. DOI: $10.3852 / 08-149$

White T, Bruns T, Lee S, Taylor J. 1990. Amplification and direct sequencing of fungal ribosomal RNA genes for phylogenetics. In: Innis MA, Gelfand DH, Sninsky JJ, White TJ (eds.). PCR Protocols: A Guide to Methods and Applications. Academic Press Inc., New York.
Yang H, Qin CS, Chen YM, Zhang GY, Dong LH, Wan SQ. 2019. Persistence of Metarhizium (Hypocreales: Clavicipitaceae) and Beauveria bassiana (Hypocreales: Clavicipitaceae) in tobacco soils and potential as biocontrol agents of Spodoptera litura (Lepidoptera: Noctuidae). Environ Entomol 48: 147-155. DOI: 10.1093/ee/nvy161

Youssef NA. 2014. Effect of certain entomopathogenic fungi and nematode on the desert locust Schistocerca gregaria (Forskal). Ann Agric Sci 59: 125131. DOI: 10.1016/j.aoas.2014.06.017. 